\title{
Philosophy, Law, and Ethics of Handling COVID-19 Pandemic in Indonesia
}

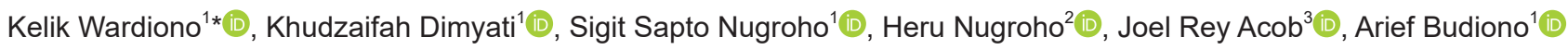 \\ ${ }^{1}$ Department of Law, Faculty of Law, Universitas Muhammadiyah Surakarta, Surakarta, Indonesia; ${ }^{2}$ Department of Law, Faculty of \\ Law, Health Polytechnic of Surabaya, Surabaya, Indonesia; ${ }^{3}$ Department of Nursing, Visayas State University, Leyte, Philippines
}

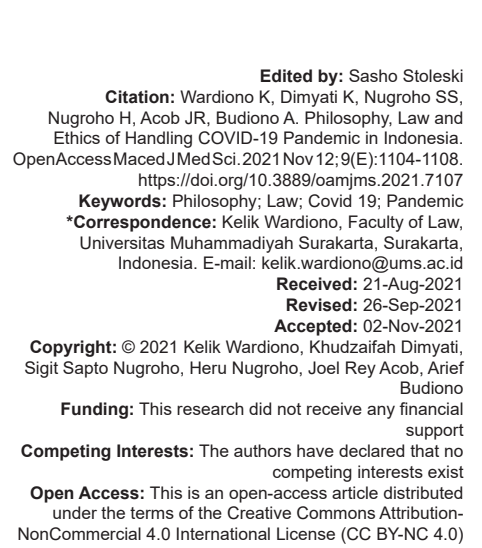

\section{Abstract}

BACKGROUND: During the pandemic, COVID-19 spread very quickly between people. Thus, the patients' rights to obtain treatment do not have to decrease the protection of the public. The perspectives of ethics, law, and justice prioritize the rights of the public as stated in the principle "Salus Populi Suprema Lex Esto" (Public safety is the highest law as regulated in the law).

METHODS: This research employs the statute approach with comprehensive, all-inclusive, and systematic manners to the ratio legis of the Health Law. It also uses the philosophy approach.

RESULTS: In Indonesia, the regulatory handling of the COVID-19 pandemic is based on the Law on Infectious Disease Outbreak. During the COVID-19 pandemic, the quick spread of this disease causes many fatalities. Thus individual rights of patients must be ruled out to prioritize public rights.

CONCLUSION: The legal perspective upholds the "Salus Populi Suprema Lex Esto" principle, namely, public safety is the highest law was the core of philosophy, law and ethics handling covid 19 pandemic.

\section{Introduction}

Article $28 \mathrm{H}$ clause (1) of the Republic of Indonesia's 1945 Constitution states, “...every person has the right to live prosperously both physically and mentally, to have shelter, to live in a good and healthy environment, and to obtain health services..." Then, clause (2) states, "... every person has the right to obtain ease and special treatment to acquire the same opportunities and benefits in achieving equity and justice...".

The regulations above are further regulated in Law No. 4 of 1984 on Infectious Disease Outbreak (hereinafter called the Law on Infectious Disease Outbreak) and Law No. 6 of 2018 on Health Quarantine (hereinafter called the Law on Health Quarantine). These two laws regulate the entrance and exit of individuals to sources of the outbreak, isolation, areal quarantine, vaccination, etc.

Apart from that, Law No 36 of 2009 on Health (hereinafter called the Law on Health) stipulates the norms that regulate the public on health. This is absolutely required to create order and to fulfill the rights of the people as health service users and as health workers. Rights occur due to the obligations of others and vice versa. This equilibrium must not be violated, as an imbalance will cause chaos [1].
The Philosophy of ethics critically analyzes how people must act in concrete situations or how they should think critically on right or wrong that may be given responsibility for, by considering various interests, rights, and responsibilities, as well as the choice to choose what can or cannot be carried out.

The case of equilibrium between rights and responsibilities stated above is seen in the current phenomena of the COVID-19 pandemic, where there are clashes between individual and public rights. In this case, individual rights include the right to undergo activities freely and to fulfill economic rights. Meanwhile, public rights include the right to live in a healthy environment and to achieve a good degree of health [2].

The COVID-19 may spread through droplets when humans directly interact. In a short period, this virus has infected people in a hundred countries in the world [3]. The latest confirmed COVID-19 data up to June 27, 2021, states that 3,287,727 were confirmed as positively infected by the virus, 2,640,676 people healed, and 88,659 people died [4]. Although it can be said that COVID-19 is not as scary as the Black Death that hit Wittenberg in 1527, or the Plague of Cyprian in 249-262 AD that caused 5000 deaths a day [5]. 
The COVID-19 is a self-limiting disease [6] that allows the human body to build its own antibody. Furthermore, this virus is easily transmitted from one person to another [7]. The spread of this disease causes people to become worried and scared. Some people rejected COVID-19 patients and the burial of their bodies [8]. Some health workers who treated the COVID-19 patients were also outcasted from their residential areas [9].

As the formulator, the implementer, and the supervisor of the regulations on social protection, the Indonesian government must consider many things, to achieve justice as a manifestation of patients' and society's constitutional rights. The law aims to achieve a sense of justice in society. Legal justice is not only formal procedural that is based on normative laws that are far from morality ethics or values of humanity. However, substantive justice is based on public morality values and human values that may bring happiness and satisfaction to society.

The government-made health regulations must consider ethical values [10]. Article 56 clause (2) letter of Law No. 36 of 2009 on Health is referred to in controlling the spread of the COVID-19. It states that the right to accept or to reject does not apply to disease sufferers whose disease may quickly and extensively infect the public. This article becomes a limitation to patients' rights. It is also an effort to protect society from the chance to be infected by the virus from suffers. Thus, there is a dilemma between ethics, law, and justice. On the one hand, the patients have the right to accept or reject treatment. Meanwhile, on the other hand, the consideration for social safety is more important when rights must be violated to achieve justice for everyone.

According to the philosophy of ethics of Immanuel Kant, there is a way of thinking or a perspective that takes ethical actions holistically and comprehensively, namely, deontological ethics. It is a method of ethical thinking that is based on objective norms or principles that must be applied in all situations and conditions [11], [12].

A concrete manifestation during the COVID-19 is that ethics, law, and justice must be prioritized in the aim to extensively maintain the health and the protection of the public from the impacts of the COVID-19 pandemic. As in the "Salus Populi Suprema Lex Esto" principle, public safety is the highest law [13]. Based on the background, this research aims to explore the perspectives of ethical philosophy, law, and justice on the patients' treatment rights during the COVID-19 pandemic in Indonesia.

\section{Methods}

This research uses the statute approach [14] that is comprehensive, all-inclusive, and systematic toward the Law on Health to analyze the ratio legis [15] of the norm's application to prevent the spread of infectious diseases as formulated in Article 56 of the Law on Health. It uses the philosophical approach [16] to analyze the ethical, legal, and justice aspects of that article. Then, the writer gives critical notes on its legal normalization and implementation with the hope to provide holistic, radical, and profound justice to the legal interests of individuals and society during the COVID-19 pandemic.

\section{Results}

\section{COVID-19 treatment rights in the} perspective of the philosophy of ethics

Philosophically, the state ideal is written in the 1945 Constitution, namely, to protect all Indonesians and their struggles. It gives an understanding that the state must protect the citizens from all threats, including the COVID-19 pandemic.

In Indonesia, the regulatory handling of the COVID-19 pandemic is based on the Law on Infectious Disease Outbreak. It is hoped to achieve the highest degree of health for the Indonesian people [17]. Then, the Law on Health Quarantine is also used to handle the COVID-19 pandemic.

A similar thing is regulated in Article 56 of Law No. 36 of 2009 on Health, which states that:

1. Every person has the right to receive or to reject part or all treatment actions that will be carried out on them after fully receiving and understanding the information on the action

2. The right to accept or to reject as stated in clause (1) does not apply to:

a. Disease sufferers whose disease may quickly and extensively infect the public

b. A person who is unconscious; or

c. A person with severe mental illness.

The stipulations above implicitly acknowledge that all patients have the right to reject or to receive all types of treatments after obtaining the information delivered by the health workers. This right is also stipulated in Article 45 of Law No. 29 of 2004 on Medical Practices, where health workers are obliged to deliver information before undergoing medical action [18].

The basic rights of the patients also include the right to participate, as stipulated in Article 32 letter $k$ of Law No. 44 of 2009 on Hospitals, namely, "(Patients have the right) to give approval or to reject actions that will be carried out by health workers on the diseases they suffer".

Article 56 of the Law on Health states that the participative right of the patients on their decisions 
regarding themselves is ignored for the state to run its obligation to protect the people's rights to be protected from being infected by the COVID-19. It is a greater responsibility to protect the safety of the people in general [19]. The Law on Health clearly regulates that patients' rights are limited when they suffer highly infectious diseases (Article 56 clause (2) letter a).

The health right is not merely fulfilled by the state carelessly. But it must fulfill certain standards of appropriateness according to human dignity. This is parallel to the stipulations of the Stockholm Declaration in 1972, which gives patients the right to determine their own fate and the right to information. Karel Vasak divided three human right generations during the French Revolution, namely liberté, égalité, and fraternité. He also argued that the main aspect of the equality concept is communication and teamwork [20].

According to the philosophy of ethics, the job of the civilization is to maintain a humane community of people through the management of law and justice. Ethically, every honor includes responsibilities and obligations that are equal to that honor. According to the philosopher Cicero, the "neminem non laedere" principle is positioned as a principle of justice in social and legal lives, where justice means not disturbing other people's rights. Respecting the rights of the public, society, and the state means that we have indirectly become just [21].

As a legal state, Indonesia has determined the 1945 Constitution as its constitutional basis. Article 28D clause (1) states, "Every person has the right for just legal acknowledgement, guarantee, protection, and certainty and also the same acknowledgement in the face of the law". Patients with infectious diseases have the same rights as other patients in general. The patients of these infectious diseases still have their participatory rights protected, namely to participate in the treatment and to express their thoughts in the form of acceptance or rejection. It is protected in Article $28 \mathrm{E}$ clause (2), "Every person has the right to believe in beliefs, to express thoughts and attitudes, according to their conscience".

According to the philosophy of ethics, according to Kohlberg, one's ethical awareness is divided into three stages, namely: (1) Pre-conventional (childish) that is oriented to punishments and moral actions are instruments, and (2) conventional, where one depends on oneself. The goodness or the badness of a person is assessed by other people and the law is objective, and (3) post-conventional, where the law that is issued must be complied with. It is oriented from the mind and the law is based on conscience (awareness of the mind) [21]

Thus, based on the philosophy of ethics, there is the task to maintain humane community civilization through law and justice by upholding the principle to not disturb other people's rights and to respect the rights of many. Social and stately rights may be morally taken accountability for.

\section{COVID-19 treatment rights in the perspective of law}

The Law on Health has a philosophical basis as ratio legis that answers why this law is issued. One of the aims of this philosophy is stated in the preamble letter b, "The activities in the effort to maintain and to increase the society's highest degree of health are carried out based on the non-discriminative, participative, and sustainable principles to create Indonesian human resources, and to increase the nation's resilience and competitiveness for national development". The right to reject or to accept the health services that will be employed to a person is an important element in the protection of the patient's rights for his/her body. This also includes COVID-19 patients.

Article 56 clause (1) of the Law on Health states, "Every person has the right to receive or to reject part or all treatment actions that will be carried out on them after fully receiving and understanding the information on the action". This clause contains a participatory element, as all elements of the communication process and the right to express opinions is well-regulated in the Republic of Indonesia's state constitution, the Law on Medical Practices, the Law on Hospitals, as well as the Declaration on Human Rights.

The mandate of the Law on Health is created due to a juridical and sociological condition that the increase of the society's highest degree of health is carried out based on the non-discriminative and participative principles. Thus, the fulfillment of rights and the protection of the rights to reject or to accept part or all of the medical treatment that will be employed on a person becomes a fundamental element that is protected according to this Law on Health.

A problem arises when this COVID-19 is easily transmitted between people. Thus, Article 56 clause (2) of the Law on Health letter exists to protect the public from the chance to be infected. This is faced with the individual rights to be involved in the treatment process on themselves and the social rights. There is a contradiction between the stipulation on clause (1) and that on clause (2) letter a, where there are exceptions on the right of the former. The right is cancelled when a person suffers from a contagious disease such as COVID-19. Legally, the state acts for its existence in carrying out its obligation to protect citizens from the COVID-19 pandemic. This is according to the ideal mandated by the Law on Health to achieve the highest degree of public health.

\section{COVID-19 treatment rights in the perspective of justice}

The Law on Health has included participatory rights and non-discriminative rights in its preamble. Then, some questions emerge, "How is the justice on the rights of the public to not be infected? Should not 
the rights of the public be protected, even by sacrificing the interests of some people?"

This theory on justice has been discussed millennia ago, both by Plato (427-347 BC) and Aristoteles (384-322 BC). The former opines that the enforcement of justice is the highest law and it must become the aim of the state. Other theories on justice that emerged in the Modern era are often used as solutions when choosing between individual and public interests [22].

The theory is known as the Theory of Utilitarianism justice. Even though the consequentialism concept that becomes the basis of this thought was developed by Richard Cumberland in the $17^{\text {th }}$ century, it was then continued by Francis Hutcheson up to David Hume. Even so, Jeremy Bentham (1748-1823) is the figure who provided the most understanding on this theory. This Utilitarianism theory believes that the good and the just are those that bring happiness, meanwhile the bad and the unjust are those that cause suffering. Bentham's proposition, namely, "The greatest happiness for the greatest number" often becomes the benchmark of many justice theories [23].

This theory received sharp critics. It is even regarded as unethical and unjust by Dworkin and Nozick. They believe that utilitarianism that prioritizes the majority's welfare will ignore the interests of minorities or individuals that are not represented by the majority. Their rights will be violated or even eradicated [24].

Ignoring individual rights for the sake of the public's rights becomes a moral and justice issue that will never be resolved. Even, this utilitarianism justice contradicts the most basic concept of justice that is contained in ius romanum, namely, tribuere sun cuique, that may be translated freely as, "Giving everyone their rights" [25]. During the COVID-19 pandemic, the quick spread of this disease causes many fatalities. Thus, individual rights of patients must be ruled out to prioritize public rights, as stated in the principle, "Salus Populi Suprema Lex Esto" where public rights are the highest law [26].

\section{Discussion}

The juridical note on the norm of Article 56 clause (2) letter that clashes individual rights (the right to accept or to reject) and public rights (the right to be protected from the threat to be infected) is an unresolvable point. This basic right (to accept or to reject) needs not to be eradicated, as it does not have to be interpreted as eradicating the obligation of that patient to not infect the disease to other people. The public's interest is the highest law. It cannot be discounted, to prevent the spread of the coronavirus and to prevent the increase of fatalities (Table 1).

Table 1: Law and health: A study on moral and justice relations during the COVID-19 pandemic in Indonesia

\begin{tabular}{|c|c|c|c|}
\hline Substance & $\begin{array}{l}\text { Perspective of Philosophy of } \\
\text { Ethics }\end{array}$ & $\begin{array}{l}\text { Perspective of } \\
\text { Law }\end{array}$ & $\begin{array}{l}\text { Perspective of } \\
\text { Justice }\end{array}$ \\
\hline $\begin{array}{l}\text { The right to } \\
\text { accept or to reject } \\
\text { treatment during } \\
\text { the COVID-19 } \\
\text { pandemic }\end{array}$ & $\begin{array}{l}\text { Thinking critically to act according } \\
\text { to situations and concrete } \\
\text { conditions to not violate other } \\
\text { people's rights, respect the } \\
\text { rights of the majority or the } \\
\text { state that may be morally taken } \\
\text { accountability for }\end{array}$ & $\begin{array}{l}\text { Citizen safety is } \\
\text { the highest law }\end{array}$ & $\begin{array}{l}\text { Giving } \\
\text { everyone their } \\
\text { rights, including } \\
\text { social and } \\
\text { stately rights }\end{array}$ \\
\hline
\end{tabular}

\section{Conclusion}

According to the perspective of the philosophy of ethics, the right to accept or to reject treatment during the COVID-19 pandemic teaches us to think critically and to act according to concrete situations and conditions by considering moral aspects that may be taken accountability for as tribuere sun cuique that may be translated freely as, "Giving everyone their rights". The legal perspective upholds the "Salus Populi Suprema Lex Esto" principle, namely, public safety is the highest law. Then, the perspective of justice regards justice as not disturbing other people and respecting the rights of many, as well as the social and stately rights as stated in Bentham's ideal, "The greatest happiness for the greatest number".

\section{References}

1. Nugroho SS. Directing to the philosophic thought of holistic legal studies: A critical analysis on positivistic legal studies to post-positivistic using the chaos theory of law. Yustisia Merdeka. 2015;1(2):21-34.

2. Absori A, Nugroho SS, Haryani AT, Sarjiyati S, Budiono A, Nugroho HS, et al. The prospect of environmental law to achieve healthy environmental development in Indonesia. Med Legal Update. 2020;20(1):204-8.

3. Shereen MA, Khan S, Kazmi A, Bashir N, Siddique R. COVID19 infection: Origin, transmission, and characteristics of human Coronaviruses. J Adv Res. 2020;24:91-8. https://doi. org/10.1016/j.jare.2020.03.005

PMid:32257431

4. COVID-19 Indonesia. The Indonesian Government's Site on COVID-19; 2021. Available from: https://www.covid19.go.id [Last accessed on 2021 Jun 28].

5. Nugroho HP. Ethicolegal right to reject treatment during the pandemic: Clashes between individual and public rights. J Indonesia Health Law. 2021;1(1):33-48.

6. Gupta R, Ghosh A, Singh AK, Misra A. Clinical considerations for patients with diabetes in times of COVID-19 epidemic. Diabetes Metab Syndr. 2020;14(3):211-2

PMid:32172175 
7. Maghzi $A H$, Houtchens MK, Preziosa $P$, lonete $C$, Beretich BD, Stankiewicz JM, et al. COVID-19 in teriflunomide-treated patients with multiple sclerosis. J Neurol. 2020;267(10):2790-6. https://doi.org/10.1007/s00415-020-09944-8

PMid:32494856

8. Navisa FD, Nafisah R. Legal protection for families of deceased patients COVID-19 patients on the rejection of burial. Yurispruden J FH. 2020;3(2):137-49.

9. Syarif $\mathrm{H}$, Jufrizal $\mathrm{J}$, Maurissa $A$. The movement to minimalize negative stigmatization to health workers due during the COVID19 pandemic. Logista. 2020;4(2):186-91.

10. Illahi BK, Haykal H. Principles and dynamics of emergency state funds in overcoming the COVID-19 pandemic. J Rechts Vinding. 2021;10(1):1.

11. Budiono A, Absori, Harun, Nugroho HS, Dimyati KK, Wardiono $\mathrm{K}$. The ideal management of health insurance for Indonesia according constitution. Calitatea. 2021;21(176):48-50

12. Tanya BL. Law Enforcement in Ethics. Yogyakarta: Genta Publishing; 2011. p. 12.

13. Pratiwi DK. Issues on the President's Constitutional Authority in Overcoming COVID-19. Jakarta: FH UII Press; 2021. p. 321.

14. Absori $A$, Yulianingrum AV, Dimyati $K$, Harun $H$, Budiono $A$ Disemadi HS, et al. Environmental Health-Based Post-Coal Mine Policy in East Borneo. Open Access Macedonian J Med Sci. 2021;9(E):740-4.

15. Kristanto K, Nurjaya IN, Madjid A, Djatmika P. Ratio legis regulation of the BPK as the only one authorized state institution declaring country financial damages in the president of 23 paragraph (1) change constitution of the 1945 constitution. Int J Multicult Multirelig Underst. 2020;7(2):519-26.

16. Bietti E. From ethics washing to ethics bashing: A view on tech

Author Query???

AQ9: Kindly provide six authors before et al ethics from within moral philosophy. In: Proceedings of the 2020 Conference on Fairness, Accountability, and Transparency; 2020. p. 210-9. https://doi.org/10.2139/ssrn.3914119

17. Nurhalimah S. COVID-19 and the public rights for health Salam, Islamic Social and Culture J. 2020;7(6):543-54. https:// doi.org/10.15408/sjsbs.v7i6.15324

18. Hulu VT, et al. Public Health Promotion. Indonesia: Yayasan AQ9 Kita Menulis; 2020. p. 38.

19. Utoro D. The law and patients' rights in obtaining medical treatment during the pandemic era. J Law, Economic and Develop. 2020;9(1):65-79.

20. Rhona KM, Smith $\mathrm{NH}$, James K, Fuller D, Wellington M, Armen $\mathrm{G}$, et al. The Law of Human Rights. Yogyakarta: Pusat Studi Hak Asasi Manusia UII; 2008. p. 243.

21. Nugroho SS. Soul of Law, Conscious Justice. Ponorogo: Uwais Inspirasi Indonesia; 2020. p. 111.

22. Ujan AA. Developing the Law, Defending the Justice of Legal Philosophy. Yogyakarta: Kanisius; 2009. p. 78.

23. Dimyati N, Nashir H, Elviandri E, Absori A, Wardiono W, Budiono A. Indonesia as a legal welfare state: A prophetic-transcendental basis. Heliyon. 2021;7(8):1-8.

24. Faiz PM. Teori keadilan John Rawls (John Rawls' theory of justice). Constit J. 2009;6(1):135-49. https://doi.org/10.2139/ ssrn. 2847573

25. Marin M, Botină M. Legal rules in ancient Rome between law, morality, and religion. Scientia Moralitas Int J Multidiscip Res. 2020;5(2):16-23.

26. Pratama KJ. A critical analysis on the interpretation of public health emergency as an emergency condition based on the legal perspective. Natl Law Magazine. 2020;50(2):281-93. https://doi.org/10.33331/mhn.v50i2.76 